\title{
CONCEPTUL DE GROTESC - FUNDAMENTARE ESTETICĂ ŞI TEORETICĂ
}

\begin{abstract}
Cofan Alunița, Conceptul de grotesc - fundamentare esteticã şi teoretică [The concept of the grotesque - aesthetic and theoretic foundation]. Studia Romanica Posnaniensia, Adam Mickiewicz University Press, Poznań, vol. XXXVI: 2009, pp. 165-177. ISBN 978-83-232-2035-0. ISSN 01372475 .
\end{abstract}

In the following paper, The concept of the grotesque - aesthetic and theoretic foundation, we are interested in reconstructing the aesthetic identity of the grotesque. This is a difficult task since the grotesque can be recreated like a puzzle from at least two different aesthetics: the ugly (the hideous, the horrible, the monstruous) and the humorous (the sinister, the macabre, the black humour). Afterwards, by examining the relation between the grotesque and different eras and literary movements, we will show that the grotesque is after all an aesthetic category which belongs to some revolutionary and modern artistic knowledge. In essence, beyond the difficulty to circumscribe and define the grotesque, we have identified three of its invariants: polymorphism, contradiction and excess.

« Frumosul are o singurâ înfăţişare, urâtul, o mie ».

(Victor Hugo, în prefaţa la Cromwell)

\section{INCURSIUNI ISTORICE ŞI SEMANTICE}

Deşi, uneori, întoarcerea în urmã pe firul istoriei pentru stabilirea etimologiei unui termen sau a sensului originar al acestuia poate părea o rătăcire zadarnică printr-o suită de transformări şi deveniri ulterioare care mai păstrează doar o vagẫ urmă cu punctual de plecare, totuşi o astfel de ,arheologie” semantică se dovedeşte adeseori beneficã pentru scoaterea din ascundere a acelui sine inalterabil al conceptului examinat. Ceea ce ne-a determinat întoarcerea la „obârşie” a fost faptul că, în destule lucrări şi studii ce-i rezervau, mai mult sau mai puțin un loc subsidiar, grotescul era recurent în combinații cu alți termeni precum : bizar, burlesc, pitoresc, diform, monstruos, fantastic, oribil, înspăimântător, caricatural, absurd. Aşa s-a 
creat, în mintea noastră, o stare de perplexitate interogativă, deoarece se înfățişa caleidoscopic şi cu o extremă ambiguitate, destructurantă, şi părea sã se topească în acești „vecini” contextuali, preluând câte ceva de la fiecare. De la bun început, neam pus aşadar întrebarea dacă, dincolo de asocierile lexicale cumulative în care fusese plasat, grotescul posedă un ,ceva” al sẫu, esenţial și inalienabil, sau dacă el se formează într-adevắr, ca un puzzle, dintr-un cumul de alte semnificații împrumutate de la alți termeni. Natura paradoxală, hibridă şi contradictorie a grotescului, imposibil de surprins în termeni clari, ni s-a relevat pe parcursul cercetấrii noastre. Şi totuşi...

Orice caricaturã este oare grotescă, având în vedere că modul caricatural de a vedea şi simți lumea este una din punțile de trecere spre grotesc? Credem că nu. Simpla deformare sau îngroşare a unui element fizic din înfăţişarea cuiva, de pildă alungirea peste măsură sau supradimensionarea nasului, încadrează acea reprezentare într-un portret caricatural, apropiat de originalul din natură, dar, dacă adăugăm chipului nişte urechi de măgar sau un rât de porc, caricatura noastră s-a metamorfozat într-un desen grotesc, respingător şi rizibil în acelaşi timp, de unde nu era, în prima etapă, decât rizibil. In privința apropierii de adevărul redãrii, a cunoaşterii prin caricatură, Bergson susține cã: „multe caricaturi sunt mai asemắnătoare decât portretele" (Bergson, 1997: 24). Transformarea ulterioară împinge imaginea dintrun plan al realului şi al percepției directe, cvasi-imitative, într-un plan al irealului şi al fanteziei eruptive, dezlănțuite. De aici se vede că grotescul este un mod de a concepe (imagina) şi nu de a percepe lumea şi e uşor sã sesizãm înrudirea lui cu monstruosul şi fantasticul, dat fiind cã şi acestea din urmă sunt categorii ale irealității. În acest sens trebuie înțeleasă afirmația lui W. Kaiser referitoare la grotesc: el este creație, nu imitație (Popa, 1975: 179) şi pune rizibilul şi monstruosul într-un insuportabil antagonism, bazându-se pe efecte extreme şi violente şocuri psihice (Popa, 1975: 180).

Originea italiană a termenului indică drept referent „grota”, ,,subterana” (Encyclopedia Universalis, 1990, vol. 24) (amintind indubitabil de descoperirile unor ruine romane ,înfundate” sub pământ, din secolele al XV-lea şi al XVI-lea), adică ceea ce este ascuns, invizibil unei percepții directe, superficiale şi obişnuite, ceea ce poate fi găsit numai dupã îndelungi şi intenționate căutări, ştiind sau imaginându-se cã acel ceva mascat şi ascuns trebuie să existe. O subterană lasă impresii contradictorii şi prima senzație este aceea de spaimă, de teroare. În orice caz, ea înşeală privirea şi aduce întotdeauna surprize şi nu dintre cele agreabile.

În secolul al XVI-lea, termenul desemna mai precis componente şi motive ornamentale, având specific simbioza regnurilor şi a formelor extrem de variate şi abundente (cu posibile influente arabe şi hispanice : de aceea va exista o echivalențã a lui cu arabescul (Popa, 1975: 174-175) în secolul al XIX-lea, la romantici E.A. Poe, Baudelaire, Th. Gautier) : frunzişuri, flori, fructe, animale reale, dar şi fantastice (grifoni, centauri, himere, sirene etc). Ingredientul principal îl constituia libertatea combinărilor şi asocierilor, opuse clar unei viziuni raţionale şi logice. 
Decorațiile de acest fel erau folosite pe ziduri, coloane, bolți, fântâni, canaturi ale uşilor, mobilă, obiecte de uz domestic şi, evident, ele ascundeau denaturând (cel puțin la o primă impresie) obiectul în care erau încastrate. Aşa încât, deşi rostul strict funcţional al unora (de pildă o servantă, un scaun sau o solniță) nu dispărea cu totul, ele puteau foarte bine să sugereze o deviere de la destinația lor practică spre o contemplare frământată de neliniști. Am adăuga, parafrazându-l pe V. Hugo, că, dacă urâtul este o formă a imitației ,servile” față de natură, o copie de tehnician sârguincios, grotescul înseamnă deja artă (Hugo, 1982: 287), o ficțiune cu legi personale în care numai meandrele bunului plac şi ale capriciului visător au relevanță. Oricum, lucrurile prinse în pãienjenişul motivelor groteşti se metamorfozează, inducând în privitor senzații incomode de incertitudine şi angoasă. Staticul obiectual prinde viață, se mişcă şi impune, într-un mod dedublat, o atmosferă alunecoasă, fantasticã şi neverosimilă, care provoacă şi pune la treabă imaginația firilor sensibile. În asemenea spații ale prezenței lor, fără ele, totul ar fi cuminte, aşezat şi liniştitor, de o banalitate strivitoare care n-ar stârni sau ,agăța" privirea.

Pentru a ne apropia cu încă un pas de semnificațiile lui, să reținem această capacitate a grotescului de a-şi ascunde adevărata identitate, de nu se dezvălui cu uşurinţă, de pắrea altceva, fiindcă îndărătul lui se află întotdeauna o surpriză contrariantă şi şocantă. E clar că el pune problema autenticului ori a autenticității, jucându-se cu mai multe identități. De aceea este atât de greu să-l definim în temeni precişi şi siguri, pentru că, versatil şi alunecos, grotescul reuneşte în sine atât un cumul de aspecte (şi.... şi...), cât şi o disjuncţie negativă (nici... nici...). Vorbind în termeni emblematici, ceea ce-l caracterizează cel mai bine este masca, travestiul, deghizarea. Aşa cum măştile populare sau de carnaval propun cel puțin două identitắţi, cea vizibilã dintr-o dată şi cea din spatele vizibilului, grotescul îşi prezintă dintr-o dată, simultan şi cu ,sinceritate”, multiplicitatea de fețe. Însă actul mascării atrage atenţia, din punct de vedere ontologic asupra unei potențiale imposturi sau falsități, pentru că ceea ce, în exterior, poartă un semn, în interior, îndărătul măştii, poate apărea un semn opus, coexistent cu primul. Semnele sunt nu numai opuse, dar şi ireconciliabile (Cãlin, 1966: 65) ; nu se actualizează, prin grotesc, o simplă antiteză de termeni contradictorii (se ştie cã, in orice relație de antinomie, termenii corelaţi îşi selectează opusul lor pe baza a cel puțin un sem comun), ci o coexistențã de aspecte şi forme care sunt anevoie, aproape imposibil, de plasat împreună. Râsul şi plânsul, tragicul şi comicul, sublimul şi ridicolul, frumosul şi urâtul, adunate în aceleaşi cuprins şi manifestate în acelaşi timp, creează distonanțe interioare care străbat în afară ca nişte strâmbături, schimonoseli, grimase şi desfigurări. Practic, privitorul însuşi este supus din partea obiectului grotesc unor reacții divergente dintre care fac parte repulsia şi fascinația exercitată de repulsiv.

Dată fiind complexitatea estetică a grotescului, nu este deloc de mirare să-l regăsim de-a lungul istoriei în diferite epoci pentru care modalitătile artistice ale reprezentării se depărtau de natură, de realitate, iar amestecul de genuri literare 
constituia o necesitate. Aşa stând lucrurile, este vădit că pentru aceste manifestări şi fenomene artistice, conceptul de imensis nu avea nici o relevanţă. Înainte însă de a urmări fenomenologia grotescului, e necesar să facem câteva distincții operatorii. Prima se referă la o disociere, mai mult formală, între grotescul popular, de extracție folclorică, care răsare oribil, monstruos şi burlesc în basme, mituri, legende, farse, snoave şi bestiare, şi grotescul savant, prelucrat de mari conştiinţe artistice, precum Dante, Rabelais, Cervantes. A doua distincţie are legătură cu modurile de manifestare ale grotescului în universul imaginar, care sunt în număr de trei şi se canalizează pe următoarele făgaşe : 1. figuri, personaje ; 2. situaţii, atmosferă şi 3. limbaj. De bună seamă că între aceste separări formale se aplică principiul vaselor comunicante, chiar dacă doar unidirecțională, cum se întâmplă adesea în relația dintre popular şi savant, devreme ce marii scriitori s-au apropiat întotdeauna de filonul popular cu o anumită aderență intimă şi pasională, conştienții fiind că aflã în el un specific al modului lor de a fi în lume. Apoi, dacă figuri, personaje şi situații groteşti le întâlnim din abundență în universul popular, grotescul de limbaj e o categorie care aparține prelucrării culte, savante. Şi când spunem ,grotesc de limbaj” ne referim la tot felul de „,manierisme”, în special la cele din secolul XX, de extracție avangardistă ori din plămada teatrului absurd (Munteanu, 1989: 5-139), dar nu putem evita referirile al unele curente sau tendinte literare de la sfârşitul secolului al XVI-lea şi începutul celui următor, precum eufuismul, gongorismul, bembismul şi prețiozitatea. Intrăm astfel pe teritoriul celei de-a treia distincţii operatorii : cea dintre grotescul intenționat şi neintenționat. Primul este rezultatul voluntar al unei concepți artistice (aşa cum e cazul „neomanierismelor" secolului $\mathrm{XX}$ ), iar al doilea se află în strictă dependență de conştiințe receptoare, cã́ci în viziunea artistică originară $\mathrm{n}$-a existat defel o astfel de intenție (e cazul manierismului istoric de la sfârşitul secolului al XVI-lea). Oricum, voluntar sau involuntar fiind, apar destul puncte comune între cele două categorii de „isme”. Cel mai important şi edificator pentru amândouă este disjuncția ,abisalâ” dintre formă şi conținut. Rezultatul este apariția unui limbaj abscons, ininteligibil, care nu comunica „ceva” decât cu mare greutate sau nu mai comunică deloc, fiindcă nu mai există sens în lume. Receptarea e blocată ori prin obscuritatea ornamentalã (Shearman, 1983: 151) ori prin devidarea cuvintelor de sens (asociații aleatorii, enumerări verbioase, repetiții în structuri identice). Pledãm, deci, pentru existența unui grotesc formal şi împotriva unor opinii negatoare în această privință care susţin că el nu e legat nici de manierism, nici de absurd (Popa, 1975: 180). În fond, absurdul este hidosul teoretic, noțional şi rațional, iar scârbosul şi repulsivul este hidosul senzorial, după formularea unui estetician postkantian, Karl Rosenkranz (Rosenkrantz, 1982: 277). Un alt teoretician, de data aceasta român, al stilurilor, Edgar Papu, recunoaşte că modalitatea grotescă se serveşte de un limbaj confuz, obscur, incoerent, reprezentând mostre de anarhie verbală şi de haos sintactic şi cuprinzând, în acelaşi timp, o obezitate a frazei, golită de sens (Papu, 1986: 163). 


\section{GROTESCUL ÎN RELAȚIA CU ANUMITE EPOCI ŞI CURENTE LITERARE}

Îl vom căuta, încercând să-i circumscriem afinitățile, numai în acele epoci, curente şi modalităţi artistice pentru care realitatea era nemulțumitoare şi prin intermediul cărora, scriitorii, exprimându-se creator, îşi alegeau refugiul într-un univers al libertății fanteziei, al visului, al iluziei şi irealității. Sau, pur şi simplu, evadarea constituia o metodă de cãutare a esențelor, a arhetipurilor, asemeni celor din lumea ideală a lui Platon, a unui dincolo de realitate, mai bun şi mai pur, unde sar afla eonii, entităţi supratemporale şi temporale în acelaşi timp (Eugenio d'Ors, 1971: 179-180). Astfel, denaturarea, deformarea şi desfigurarea realității, prin prelucrarea critică, satirică sau polemică a datelor ei, sunt mijloace preferate de scriitori pentru a reliefa tarele, viciile şi urâțeniile lumii. Grotescul îşi face simțită prezența de fiecare dată când, printr-un exces de exagerare şi îngroşare sau printr-un amestec disparat şi contradictoriu, urâtul devine hidos, înspãimântă̌tor şi rizibil, fără să mai stârnească mila şi simpatia, cum se putea foarte bine întâmpla in cazul urâtului pur si simplu.

Aplicând o tăietură în diacronie, descoperim prezența grotescului uneori în epoci succesive, fapt deloc surprinzắtor, dacă ne gândim că formele şi curentele literare curg unele într-altele, că ele nu sunt atât de opuse pe cât vor sã crediteze impresia, fiindcă, de fapt, atitudinile antitradiționale pe care şi le arogă unele pornesc de la tradiția inaugurată de precedentele. Renaşterea, barocul, manierismul, romantismul, expresionismul şi ,neomanierismul” [în acest concept includem curentele de avangardă de la începutul secolului nostru, după încadrarea ce-o face Edgar Papu (Papu, 1986: 496)] se întâlnesc prin anumite ramnificații estetice ale lor, pe zone mai întinse sau mai restrânse, cu grotescul. Înrudirea între anumite fenomene literare este recunoscută şi de Lucian Blaga, atunci când demonstrează analogiile şi deosebirile dintre romantism şi expresionism, „noul stil” al veacului XX (Blaga, 1990: 90). Dintre toate, dacă punem la socoteală afirmațiile lui Dan Grigorescu, pătrunzător exeget al expresionismului în literatura română, în această privință (Grigorescu, 1980: 66), expresionismul pare să aibă afinitătị de natură strânsă cu grotescul.

Să examinăm pe rând implicațiile estetice ale grotescului în fiecare din aceste curente literare şi sã vedem prin ce anume o face, prin ce aspecte este înglobat de acestea în propriile lor reprezentări. La prima vedere, apropierile „simpatetice” se realizează după cum urmează: printr-o viziune a colosalului şi a enormului cu Renaşterea [deoarece ,în artă , categoria cantității, vẵzută în proporţii uriaşe, nu aparține numai sublimului, ci şi grotescului" (Papu, 1986: 59)], printr-o extravaganţă scandaloasã şi şocantă cu barocul; prin distorsiuni şi deformări subiective exagerate cu manierismul; printr-un fantastic monstruos, terifiant şi oribil cu romantismul; prin elementaritate (însemnând o întoarcere la amorf) şi angoasant cu expresionismul; prin absurd şi caricatural cu avangarda. 
Există, de altfel, după cum confirmă un cercetător profund al Evului Mediu, E.R. Curtius, un amestec stilistic de serios şi comic caracteristic sfârşitului Antichității care poate să crească până la burlesc, considerat a fi, în accepțiile lui obişnuite, înregistrate normativ de dicţionare, un comic excesiv, grotesc, extravagant şi adesea vulgar (Curtius, 1970: 486). Lumea anticã poseda, avant la lettre, o bogată figurație populară grotescă, provenind din credințele ei politeiste şi desemnând o serie de făpturi auxiliare pe lângă marii zei : harpiile, eumenidele, tritonii, gorgonele, satirii, faunii, ciclopii, centaurii. Unele provocau râsul [,Silen este un grotesc bufon" (Hugo, 1982: 288)], iar altele înfricoşau [,,Polifen este un grotesc teribil" (Hugo, 1982: 288)]. Ele ocupau diferite roluri, mai mult sau mai puțin episodice, în epopeea comică (Homer), tragedia comică [la Euripide, fiindcă abia cu el tragedia atinge ocazional comicul (Curtius, 1970: 483)] şi în comedie (Aristofan), fără ca scriitorii antici să aibă foarte clară conştiința că o asemenea galerie de personaje ține de o contrapondere destabilizatoare față de aspirația lor spre sublim şi frumos. Să nu uităm, totuși, privind spre literatura latină, de Metamorfozele lui Apuleius şi de Satyricon-ul lui Petronius, care parodiază cu bună ştiinţă pateticul eroic, solemnul şi gravul unor lucrări contemporane sau antecesoare. Apuleius dezvoltă, de pildă, un comic grosolan în care amestecă umorul culinar cu alte ridicula (trivialitắți, obscenitắți), fapt pe care-l vom regăsi mai târziu la Rabelais, chiar dacă nici la el nu lipseşte o anumită bonomie. Polaritatea glumã-graviate a fost, începând cu Antichitatea târzie, o schemă ideatică, formală, care apare în teoria retoricắ, în poezie, în poetică, dar şi sfera idealurilor de viață. Aşadar, chiar pentru epoca imediat următoare, amestecul de hazliu şi serios fãcea parte din normele stilistice cu care erau familiarizați şi de care erau conştienți poeţii medievali, fapt ce confirmă marea trecere de care se bucurau în Evul Mediu încrucişările şi hibridizările stilistice, în orice formă (Curtius, 1970: 491).

Astfel, la Dante, reprezentativ pentru epoca medievală, Edgar Papu stabileşte, într-o analiză minuțioasă şi erudită a caracterului popular şi modern al Divinei Comedii, că grotescul formează una din laturile prin care este întrețesut în opera dantescă specificul popular. Infernul dantesc abundă, după opinia lui, în imagini în care elementul terific deformant şi totodată caricatural provoacă echivocul între spaimă şi râs, asemenea unor măş̧i de carnaval. Întrucât pe lângă utilizarea elementului deformant, consideră E. Papu, unul din procedeele obişnuite ale categoriei groteşti este şi aceea de a raporta prin comparație o scenă îngrozitoare la o reprezentare comică sau, în orice caz, jovială; prin aceasta se minimalizează efectul terifiant, lăsând să transpară $o$ intenție de satiră sau de simplã farsă (Papu, 1970: 34-35).

Un alt estetician, Mihai Bahtin, examinând într-un studiu pắtrunzắtor universul rabelaisian (Bahtin, 1982: 394), atribuie grotescului din paginile romanului Gargantua şi Pantagruel calitatea exagerării, a preciziei detaliate, a descrierii şi asocierii, şi capacitatea de a se forma din intersectarea diferitelor serii de toposuri precum: corpul uman (aspectele lui anatomice şi fiziologice), mâncarea, băutura, sexualita- 
tea, coprologicul, moartea. El remarcă că analogiile groteşti sunt alcătuite de Rabelais prin serii descriptive hiperbolizante sau prin îmbînări absurde de cuvinte (Bahtin, 1982: 400-405). Tinta grotescului este aceea de a deprecia, devaloriza, deierarhiza, o stare de fenomene şi lucruri date: „toate îmbinările lui de cuvinte (chiar acolo unde obiectual par absolut absurde) țin, înainte de toate, să distrugă ierarhia stabilită a valorilor, să micşoreze ceea ce e mare şi să măreascã ceea ce e mic, să distrugă imaginea obişnuitã a lumii sub toate aspectele ei" (Bahtin, 1982: 401).

Trecând de la grotescul Renaşterii care, după cum s-a văzut în exemplele date, dezvolta o viziune a colosalului şi a enormului, prin hiperbolizare şi amestec absurd de forme incompatibile, grotescul îşi anexează în modul său de a fi atât barocul, cât şi manierismul, prin felul în care acestea se raportează la noțiunea de mimesis. Manierismul recurge, deci, la alterarea modelului dinafară, la degradarea conceptului de mimesis cu o conştiință mai curând agresivă; pe când barocul, dupã părerea lui E. Papu, nu lezează structura naturală, o cultivă organică, dar o face să prolifereze, aşa încât devine o hipertrofiere a mimesisului (Papu, 1986: 73). În douã cuvinte, distincția dintre grotescul baroc şi cel manierist s-ar putea rezuma astfel: creația multiformă a barocului completează, în esență, creația deformată a manierismului.

Însã cea mai importantã formulare estetică şi noțională a grotescului, enunțatã clar şi programatic, aparţine romanticilor, care îşi simt oprimată libertatea creatoare de canoanele frumosului, impuse de clasici prin intermediul poeticii lui Aristotel. Criza noțiunii de frumos în artã aduce în prim planul dezbaterilor polemice problema locului urâtului în exprimarea artisticã. Victor Hugo, unul dintre franctirorii bătăliei romantice, delimitează cu o siguranță uluitoare dubla apartenentă a grotescului, în celebra teorie pe o face asupra acestuia în prefața la Cromwell, socotind că există o alianță creatoare între grotesc şi frumos, ştiind că prezența lui potențează înțelegerea şi strălucirea frumosului. Pe de o parte, îl leagă de diform şi oribil (estetica urâtului), iar, pe de altă parte, îl asociază bufonului şi burlescului (estetica comicului) (Hugo, 1982: 288-289, 290-293), făcând trimiteri exemplificatoare la fiinţele intermediare din tradițiile populare ale Evului Mediu, la hidoasele figuri ale lui Dante, la înfătişarile ridicole ale lui Callot şi la închipuirile pitoreşti (adică: bizare, insolite) ale religiei şi poeziei. Grotescul sparge monotonia reprezentările unice şi asemănătoare ale frumosului. „Lucrurile frumoase sunt acelea care se apropie de criteriul ideal. Ca să se apropie de acest etalon, ele trebuie să fie asemănẵoare. [...] frumosul, fiindcă tine de ideal, e şi el unic. Realitatea însă poate fi diversă", opinează un estetician român (Ralea, 1957: 233) şii, lucru curios, Hugo nu-l opune, ci îl aliază sublimului (ca manifestare estetică a frumosului), fără a uita să remarce contrastul hotărât pe care-1 presupune şi-l evidențiază relația dintre ele. În ciuda alianţei propuse, Hugo răstoarnă totuşi relația grotesc-sublim şi-i acordă absolută întâietate primului, pentru ca apoi sã lege această răsturnare violentă de poziții de prăbuşire arbitrarei deosebiri clasice de genuri şi de naşterea dramei, un 
gen literar nou, care ,topeşte în acelaşi suflu grotescul şi sublimul, teribilul şi bufonul, tragedia şi comedia" (Hugo, 1982: 294).

Ceva mai târziu, Baudelaire vede în grotesc ciocnirea idealităţii cu diabolicul şi absurdul, neavând, prin urmare, nimic comun cu hazliul sau comicul (Friedrich, 1969: 77). Pentru el, frumosul este un rezultat al combinării între „pur şi bizar”, bizarul fiind înțeles ca o deformare care produce surpriza sau declanşeazầ un atac neaşteptat asupra conştiinței contemplatoare. Poate că din acest mod de înțelegere baudelairiană a grotescului, asociere a idealitătii cu absurdul şi diabolicul, vor fi derivate câteva tră̌sắturi esențiale ale grotescului expresionist şi avangardist de peste câteva decenii. Deşi Baudelaire însuşi defineşte urâtul ca pe o împletire a oribilului cu bufonescul, totuşi socotim cã, în mod intuitiv, el a formulat, de fapt, ecuația estetică a grotescului.

Parte din comentatorii fenomenului literar expresionist sunt de accord în a recunoaşte înclinația şi gustul pentru grotesc al acestui curent, fie că ia forme apocaliptice (Crohmẫlniceanu, 1978: 156) (ț̂şnind din fantasticul monstruos al romantismului), fie că se arată prin figurile atroce şi lugubre ale umorului negru (Micu, 1985: 244). Pentru expresionişti, grotescul pare un teren de manifestare a sacrului, a unor forțe suprafireşti cu țeluri superioare, iar galeria de estropiați, schimonisiți, caraghioşi şi nebuni iluminați devine expresia umanității care-şi caută, sub măştile ei hlizite dureros, sufletul divin pierdut şi capacitatea de a trăi simultan oribilul şi sublimul (Crohmălniceanu, 1978: 153), ceea ce ne aminteşte de dorinţa lui Baudelaire de a exprima suferința prin râs, când suferința înseamnă măreție şi sublim, iar râsul - degradare şi înjosire. Aşadar, ființa umană este distorsionată în mod grotesc sub presiunea demoniei civilizație, a păienjenişului tentacular urban, înstrãinată de propria esență, iar expresionismul încearcă să celebreze, prin opoziție la acestea, elementarul, „forțele tumultuoase”, sacrul şi arhaicul, acţionând în expresie prin imagini brutale, violente şi agresive (Micu, 1985: 128-129).

$\mathrm{Nu}$ se poate ocoli contribuția lui A. Jarry la dinamizarea viziunii groteşti a curentelor literare de la începutul acestui secol prin trilogia sa ubuescă (Ubu rege, Ubu încornorat şi Ubu înlắntuit). Figură grotescă exemplară, Ubu este un hibrid între marionetă şi mascã, dincolo de care nu se găseşte autenticul şi adevărul ființei (ca în expresionism), ci doar ,autenticul” nimicului şi al golului copleşitor. Jarry a urmărit să satirizeze, ridiculizând agresiv, tarele şi viciile omeneşti. A pus, prin Ubu, în fața publicului nu o oglindã fidelă, realistã ori naturalistã, ci una care deformează în exces trăsăturile sancționate: „virtuosul se vede (în oglindǎ - n. mea., A.C.) cu coarne de taur şi cu un trup de balaur, potrivit exagerării viciilor lui" (Jarry, 1968: 100). În fapt, Ubu este imaginea răsturnată, îngroşată violent şi fardatã monstruos, a umanitătiii întregi. La fel de important ni se pare în opera lui Jarry, ca prezență a grotescului de limbaj, şi jargonul din rostirea ubuescă, a cărui configuraţie lingvistică se reazemă pe trivialităti, aberaţii semantice, non-sensuri şi compuneri lexicale antinomice. Celelalte personaje din jurul lui Ubu folosesc, totuşi, un 
limbaj mai decent şi inteligibil, cu toate că şi acesta este minat de o anume rigiditate a gândirii în clişee.

În anumite texte avangardiste (dadaism, futurism, constructivism) şi în teatrul sau proza absurdului (S. Beckett, E. Ionescu), limbajul este prelucrat în distorsiuni groteşti, fiindcă nu mai există putința comunicării într-o lume haotică şi lipsită de sens. Amorful ontologic se reflectă în limbaj printr-o serie de procedee între care se înscriu: palinodul, silogismul aberant sau falsul rationament, combinația de registre lingvistice eterogene, precum familiar-solemn, intim-protocolar, popular-savant. Anticlimaxul, ca procedeu al grotescului de atmosferă şi situație, fiindcă desfăşoară un tip de umor sec, reticent şi înfiorător care gliseazã pe hotarul subțire dintre tragic şi comic, este practicat de reprezentanții umorului negru, atroce, crud, macabru şi sinistru, care dă naştere unui râs schimonisit şi înghețat (Călin, 1975: 139). În astfel de situații, o istorie ce debutează grav sfârşeşte bufon şi o bagatelã comică virează spre un deznodământ catastrofic, lugubru.

\section{CIRCUMSCRIERI ESTETICE ȘI CÂTEVA CONCLUZII}

După examinarea morfologiei şi a conotațiilor grotescului în istorie, e nevoie să ne îndreptẵm atentia asupra unei perspective strict estetice a conceptului, folosindu-ne, bineînțeles, de acumulările de până acum. Un lucru reiese clar în evidență: natura grotescului nu este deloc simplă, mai mult chiar, e paradoxalā. Pentru a surprinde ceea ce-i este specific e necesar să-i disociem identitatea proprie de toate potențialele împletiri cu alte noțiuni şi concepte, fiindcă chiar acesta e unul prin principalele obiective al tezei noastre, de a-i stabili un „sine” al sắu, inconfundabil şi inalterabil, oricât ar pắrea de bizar şi preconceput să vorbim despre individualitate la o categorie estetică care destructurează şi distruge tocmai această noţiune. Constantele alcắtuitoare ale identității sale estetice, purtând, deci, semnul grotescului, ne vor ajuta sẵ-i detectắm imixtiunea într-un text şi să-1 recunoaştem ca atare. Ne-am oprit la trei caracteristici (sau invariante) care-i delimitează cel mai bine identitate categorială : polimorfismul, contradicția şi excesul.

Natura paradoxală a grotescului este vizibilă în capacitatea lui de a fi o reprezentare polimorfã a fanteziei. Polimorfismul stabileşte punțile de legătură şi tranziţia spre monstruos şi fantastic şi fundamentează înglobarea întregii figuraţii de personaje animaliere sau umanoide a căror organizare internã decurge dintr-o simbioză ciudată de elemente disparate, eterogene, în categoria grotescului. Absurdul generat de asemenea imagini tâş̧neşte din imposibilitatea acceptării logice şi raționale a unei convieţuiri de forme atât de potrivnice ordinii normale. Exemplele abundă şi nu ne-am putea opri asupra unuia fără să simțim că am defavorizat un altul, poate şi mai bun. E suficient să (re)aducem în fața ochilor noștri reproducerile de coşmar ale bestiarelor medievale care circulă încă în imaginile zoomorfe din basmele, poveştile, snoavele şi farsele populare. Impresia pe care o lasă eteroge- 
neitatea discordantă a unor astfel de întruchipări este aceea de a fi insuficient organizată (deşi fiecare parte funcționează dupã legile sale) practic amorfā, indistinctă, având câte puțin din materia unui alt regn, cắci nici o componentă nu este desăvârşită până la capăt. Intenția formatoare s-a întrerupt la jumắtate sau s-a mulțumit cu o vagă schițare. Dezordinea structurii a făcut ca el să fie asimilat cu o lume inferioară, nedesăvâşită, alcătuită din bucăti luate de ici şi de colo. Acest lucru nu împiedică creatura ivită din disparitatea formelor să asculte de legile sau princi-piile alăturate ale părților componente. Aşa ajungem la simbolul măştilor de carna-val (M. Bahtin a legat prezența grotescului de figuraţia carnavalescă, iar W. Kaiser - de absurd) care înfățişează privitorului aceleaşi distorsiuni contradictorii şi dizarmonice de forme cumulând mai multe identități, dar funcția lor este cu totul alta şi anume: aceea de a media contactul cu o lume superior organizată, divină, şi de a ascunde fețele nevrednice ale neinițiaților ce recrează temporar, prin măşti, atitudini şi comportament, atmosfera haotică, amorfă, primitivă de la începutul creației (Caillois, 1975). Se înțelege acum de ce, pentru expresionişti, măştile groteşti întruchipau o coborâre a sacrului în lume.

Cea de-a doua constantă, contradicția, dezvăluie natura permanent duală a manifestării grotescului. Nu este vorba de o banală şi simplă contradicție, ci mai mult de o reunire forțată a unor incompatibilități care pot trece una în alta sau pot coexista într-o vecinătate deformantă când pentru una, când pentru cealaltă. Aşa se explică, pe de o parte, de ce grotescul îşi bifurcă apartenența spre estetica urâtului şi spre estetica comicului. Se poate sesiza clar, după ce am detaliat concepţia modernã a lui $\mathrm{V}$. Hugo despre grotesc, că acesta înseamnă numai un anume urât (hidos, oribil, respingător) şi un anume comic (burlesc, bufon, vulgar). Grimasele, schimonoselile şi strâmbăturile hidosului nu atrag, în principiu, simpatia şi mila privitorului, ci numai reacții tensionate de dezgust, scârbă şi spaimă, pentru că el alắtură, automat şi inconsțient, hidosul diabolicului sau drăcescului care înfricoşează fiindcă maschează un rẵu posibil. Dar, pentru a exorciza sau atenua spaima resimțită în fața lui, nu e decât o soluție: aceea de a-1 „,cobor̂”” din înãlțimile înfricoşătoare cu ajutorul râsului, care, tocmai din această pricină, ajunge un ,râs chinuit” ori „strâmb”. În consecintă, o parte din modalităţile comice groteşti, care se pretează cel mai bine la ştergerea, măcar parțială, a tensiunii iscate de repulsie şi spaimã şi folosite în această situație sunt (după cum precizeazã K. Rosenkranz, 1984: 322) grosolănia limbajului, înjurăturile şi termenii obsceni. Pe de altă parte, există o serie de polaritắti a căror contiguitate şi manifestare simultană dau naştere unor efecte groteşti, precum sublimul şi ridicolul, solemnul şi vulgarul, tragicul şi comicul, suavul şi dezgustắtorul. Între componentele acestor perechi sau cupluri contrastante pot apărea permutări, dar efectele rămân aceleaşi. Eroicul, aparținând registrului solemn, sublim şi tragic, supus unei şarje ridiculizante devine grotesc. în special atunci când eroismul ține de închipuire, este un fals eroism. Şi aici atingem problema imposturii şi a falsității pe care o demască violent grotescul prin procedeele sale şi-i sesizăm, în acelaşi timp, latura critică. Pe adevăratul erou, ridicolul 
nu-l afectează, el rămâne imperturbabil şi senin în mijlocul detractorilor; defăimãtorii sunt cei care se fac mai degrabă de râs şi ridicoli, fiindcă şi-au ales prost ținta, iar tirul lor s-a întors, prin ricoşeu, asupra lor înşile. Putem detecta o anumită înțelegere a lumii şi a vieţii, aflată dincolo de ochiul deschis asupra grotescului, ca subcategorie esteticã a comicului şi a urâtului. Legătura dintre estetică ontologie şi gnoseologie a devenit aproape o tautologie, un adevắr evident: „Orice teorie estetică e condiţionată de o teorie a cunoaşterii” (Ralea, 1957: 234) sau, cu alte cuvinte: „ar fi cu totul fals să rupem fundamentele esteticii de acelea ale ontologiei" (Hartman, 1974: 511), după cum răsună opiniile consonante a doi esteticieni, unui aparținând culturii române şi celălalt culturii germane. Prin urmare, grotescul are şi el întotdeauna o latură morală, un etos, şi o latură metafizică. Aceasta din urmă desemneazã atitudinea şi poziția omului (în speță, a creatorului) față de lume, respectiv locul şi rolul pe care-l are în ordinea şi rânduiala universului.

Revenind la relația dintre sublim şi ridicol şi, acceptând aserțiunea comună ,,de la sublim la ridicol nu e decât un pas", ne întrebăm cum se face această tranziție de la unul la celălalt. După Kant, criticat de N. Hartman, în Estetica sa, în subiectul contemplator, aflat în fața sublimului, se găsesc în conflict două momente afective: unul de impotrivire sau de repulsie, un sentiment de neputință şi de teamă si, al doilea de adeziune (Hartman, 1974: 410). Ca atare, în orice valoare estetică pozitivă existã, la un moment dat, prin inducerea unui prag de sațietate şi monotonie o zonă de hotar care intră sub o incidență negativă, a reversului sumbru şi opus valorii, unde apare o nonvaloare. Pozitivul alunecă spre negativ, valoarea spre nonvaloare, numai dacă ele depăşesc un prag al mãsurii şi echilibrului.

$\mathrm{Ne}$ apropiem în acest fel de cea de-a treia invariantă a identitătịi estetice a grotescului: excesul. Aceasta nu înseamnă, pur şi simplu, exagerare şi îngroşare, trăsắturi ce țin de arta caricaturalului (și, după cum am văzut, nu orice caricatură este grotescă), ci o culminare a lor peste măsura unei putințe previzibile. Aşadar, îngroşarea şi exagerarea peste limita lor obişnuită şi „normală” împing caricaturalul în domeniul grotescului. Excesivul este o trăsătură nu numai a figurării (reprezentării spațiale), ci şi a intensității. E limpede acum în ce fel orice exces tensional, pozitiv şi valoric, se transformá în contrariul lui. În principiu, urâtul însuşi este vẫzut ca o deformare sau desfigurare (mărire, alungire, subțiere şi îngroşare a unei părți din ansamblu, din care decurg efecte distonante şi dizarmonice), însă grotescul implicã un simţ special al urieşescului şi al infimului (ori al microscopicului), aşa încât, în loc de mărire, dămm peste o hiperbolizare şi, în loc de micşorare, peste o litotă. $\mathrm{Cu}$ o butadă, născută din ideea de exces (în sensul de ,ieşit din comun” şi „nefiresc”) pe care-l cuprind însuşirile desemnate de „,insolit”, ,extravagant” şi „bizar”, putem afirma că grotescul este un urât extravagant. Cât despre obiectul plasat sub tirul necruțător al şarjei groteşti, el este desființat. Înghesuit între depreciere, devalorizare şi ridiculizare, el stârneşte reactii divergente în sufletul contemplatorului: pe de o parte - respingere şi înspăimântare, pe de altă parte o uşoară solidarizare şi adeziune. Oricât ar părea de straniu, mila şi uşoara simpatie 
pe care o resimţim în fața urâtului se perpetuează şi în cazul grotescului, uneori. Asta din pricină că îndărătul hidosului şi monstruosului fizic, a degradării corporale, poate răsări un rest de umanitate în care s-au păstrat intacte înalte valori morale (bunătatea, înţelegerea, generozitatea).

Romanticilor li se datorează această valorizare sau latură pozitivă a grotescului şi e suficient pentru a înțelege răsturnarea valorică produsă să-1 luăm în considerație pe nefericitul Quasimodo. Se întâmplă, deci, ca grotescul sã fie nedrept şi sã atace cu specifica lui cruzime nu numai acel ceva care se închipuie valoare, ci şi adevărata valoare. Orbit de pasiunea argumentării, pamfletarul poate păşi strâmb, aplicând corecțiile umorului său negru cu o voluptate verbală care uită să mai facă anumite distincții. La îndemâna noastră se află exemplul unui pamfletar de temut din perioada interbelică a literaturii române, T. Arghezi, care şarjează, ridiculizându-1 grotesc, împotriva lui Lovinescu.

Grotescul denotă, în concluzie, o retragere din fața răului existenței şi a lipsei de valoare a lumii. El sesizează, prin imagini rắsturnate şi deierarhizate, imperfecţia, falsul şi vidul din jur şi, într-un anume sens, el este o categorie estetică revoluționară care îşi doreşte, satirizând şi criticând ordinea putredã existentãa, să reîntroneze, cumva, adevăratele valori. Oricât de dezgustat şi lipsit de iluzii ar părea la un moment dat, el aspiră în secret, ca un demn ferment al mobilității şi schimbării, la etosul clasic al Antichității.

\section{BIBLIOGRAFIE}

Bahtin M. (1982), Probleme de literaturã şi estetică (cap. Cronotopul rabelaisian), Bucureşti : Univers.

Balotẫ N. (1971), Lupta cu absurdul, Bucureşti : Univers (p. 5-449, fâră pag. 137-157).

Blaga L. (1990), «Despre naturalism », in : Fełele unui veac, Bucureşti : Minerva.

Caillois R. (1971), In inima fantasticului, București : Meridiane.

Câlin V. (1975), Romantismul (cap.: Estetica, p. 13-60 ; Spiritul satiric, Ironia romantică, Feeric şi fantastic, p. 203-271), Bucureşti : Univers.

Cãlinescu M. (1987), Five faces of modernity, Durham : Duke university Press, şi ed. românească: 1995. Cinci fete ale modernitâtii (cap. Ideea de avangardâ), București : Univers.

Cãlinescu M. (1993), Rereading (cap. Rereading Borges's "The Aleph »), London : Yale University Press.

Crohmālniceanu Ov. S. (1978), Literatura românã şi expresionismul, Bucureşti : Minerva.

Curtius E.R. (1970), Literatura europeană şi Evul Mediu Latin (cap. Escursuri, IV. Glumă şi gravitate în literatura medievalâ, p. 483-504), Bucureşti : Univers.

Grigorescu D. (1980), Istoria unei generafii pierdute: expresioniştii (cap.: O artă germanică, p. 5-123 ; În literatura română, p. 372-427), Bucureşti : EE.

Hartman N. (1974), Estetica (cap.: II. Sublimul şi grațiosul, p. 403-457; III. Comicul, p. 457-505), Bucureşti : Univers.

Lascault G. (1973), Le monstre dans l'art occidental (p. 9-36), Paris : Klek. 
Marino A. (1973), Dicfionar de idei literare, vol. 1 (art.: Comedia, p. 400-408; Comicul, p. 409-442), București : Eminescu.

Micu D. (1992), În cấutarea autenticitătii, Bucureşti : Minerva.

Munteanu R. (1989), Farsa tragicã (cap. Universul grotesc, p. 5-139, 236-288), Bucureşti : Univers.

Nemoianu V. (1998), Îmblânzirea romantismului, Bucureşti : Minerva.

Papu E. (1986), Despre stiluri (cap.: Barocul, Gânduri despre manierism), Bucureşti : Eminescu.

Popa M. (1975), Comicologia (cap.: Modul satiric, Modul grotesc şi Modul ironic), Bucureşti : Univers.

Popa M. (1968), Homo fictus (cap.: Tipicitatea. Personajul stereotip; Automatele, marioneta, personajul parodic: Suprapersonajul, p. 160-214; 221-229; 229-328), Bucureşti : EPL.

Rosenkranz K. (1984), O esteticã a urâtului, București : Meridiane.

Shearman J. (1983), Manierismul, Bucureşti : Meridiane.

Wright Th. (1864), Histoire de la caricature et du grotesque (cap.: Origine de la caricature et du grotesque), Paris : Garnier Frères. 